\title{
Predicting Financial Distress: Multi Scenarios Modeling Using Neural Network
}

\author{
Mohamed Sameh Gameel ${ }^{1} \&$ Khairy El-Geziry ${ }^{2}$ \\ ${ }^{1}$ Faculty of Business Administration, Sadat Academy for management sciences, Cairo, Egypt \\ ${ }^{2}$ Faculty of Commerce, Cairo University, Giza, Egypt \\ Correspondence: Mohamed Sameh Gameel, Faculty of Business Administration, Sadat Academy for \\ management sciences, Cairo, Egypt. Tel: 002-0100-648-1258. E-mail: mohamed.sameh@ sadaacademy.edu.eg
}

Received: August 31, 2016

Accepted: September 23, 2016

Online Published: October 25, 2016

doi:10.5539/ijef.v8n11p159

URL: http://dx.doi.org/10.5539/ijef.v8n11p159

\begin{abstract}
This paper aims to investigate the best scenario to predict financial distress in the Egyptian stock market using a neural network model. The sample consists of 37 company listed on the EGX100. The sample period is eight years from 2001 to 2008, so we can isolate the effects of global financial Depression in the end of 2008, and the effect of economic instability, which coincided with the Egyptian revolution in 2011 tell now. The results show evidence that the best scenario for predicting distress in Egypt is that the company will be distressed if there is a decreasing in liquidity, decreasing in generating cash from sales with increasing in financial leverage.
\end{abstract}

Keywords: financial distress, neural network, multi scenarios, financial modeling, emerging markets

\section{Introduction}

Charitou et al. (2004) demonstrated that in the beginning of the financial forecasting modeling, there was not any sophisticated statistical methods or computers available to researchers. the first prediction way is to compare corporates financial ratios to each other and find if there is a clear difference in the ratios between the distressed and non-distressed firms.

In the 60's, researchers used statistical models to identify financial ratios that could classify companies into failure or non-failure groups. Beaver (1966) used a dichotomous classification test to identify the best financial ratios predict corporate failure. He used 30 financial ratios and 79 pairs of companies (failure/non-failure). The best ratio was the working capital/debt ratio, which correctly decremented 90 percent of the firms one year prior to failure. The second best ratio was the net income/total assets ratio, which correctly decremented 88 percent of the firms. There was a relatively few studies used the univariate model for distress prediction. Altman (1968) developed a multivariate statistical model to discriminate failure from non-failure firms. The initial sample was composed of 66 firms with 33 firms in each group. The f financial ratios used in model were working capital/total assets, retained earnings/ total assets, earnings before interest and tax/total assets, market value of equity/ book value of total liabilities, and sales/total assets. The model was extremely accurate in classifying $95 \%$ of the total sample correctly one year prior to failure (-1 year), but misclassification of failed firms increased as the prediction time increased for prediction. Ohlson (1980) used the logit model to predict business failure with a sample of 105 failing firms and 2058 non-failing firms. The financial ratios included in the model were the firm size, total liabilities/total assets, working capital/total assets, current liabilities/current assets, a dummy variable indicating whether total assets were greater or less than total liabilities, net income/total assets, funds from operation/total liabilities, another dummy variable indicating whether net income was negative for the last two years and change of net income. The model did not perform as well as altman model. Mensah (1983) used multivariate discriminant analysis and logit analysis to develop models predict business failure, he intended to predict failure 2 to 5 years before it happens. The sample consisted of 11 financially distressed companies and 35 successful companies for the period 1975 to 1978. The financial ratios included in the model were the classified to eight groups of ratios as follow:

- Short-term Liquidity Ratios: Cash to Current Liabilities, Current Assets to Current Liabilities, Current Assets minus Inventories to Current Liabilities and Working Capital to Total Assets.

- Cash Flow Ratios: Cash Flow to Current Liabilities, Cash Flow to Sales, Cash Flow to Total Assets, Cash 
Flow to Net Worth, Cash Flow to Total Liabilities and Cash Flow to Total Interest.

- $\quad$ Long-term Solvency Ratios: Net Worth to Total Liabilities, Net Worth to Long-term Liabilities, Net Worth to Total Assets, Net Worth to Fixed Assets and Net Operating Profit to Interest.

- Short-term Capital Productivity Ratios: Sales to Inventories, Sales to Accounts Receivable, Sales to Working Capital, Sales to Current Assets minus Inventories and Sales to Cash.

- Profit Margin Ratios: Net Operating Profit to Sales, Net Income to Sales and Interest to Net Income.

- Long-term Capital Productivity Ratios: Sales to Fixed Assets, Sales to Total Assets and Sales to Net Worth.

- Return on Investment Ratios: Net Income to Net Worth, Net Operating Profit to Total Assets, Net Operating Profit to Total Debt and Retained Earnings/Total Assets.

- Debt Coverage Ratios: Current Liabilities to Total Assets, Long-term Liabilities to Current Assets, Current plus Long-term Liabilities to Total Assets and Current plus Long-term Liabilities plus Preferred Stock to Total Assets.

- Price-Level Ratios: Business Income to Stockholders' Equity, Business Income to Total Liabilities, Business Income to Total Assets, Realized Gains/Losses to Total Assets and Realized Gains/Losses to Total Historical Cost Income.

The results showed that the percentage of error forecasting is $3.3 \%$ in the second year before failure. Zmijewski (1984) used the probit model to predict business failure with a sample of firms listed on NYSE between 1972 and 1978. The financial ratios included in the model were net income/total assets, total debt/total assets and current assets/current liabilities. Accuracy rate of Zmijewski's model was 95.29\%. Lane et al. (1986) used the Cox model and discriminant analysis to predict bank failure with a sample of 130 banks that failed between January 1978 and June 1984, and 334 non-failed banks. The research classification based on the computation of the surviving probability of a bank more than 24 months, based on the values of financial ratios of the bank based on data from a prior year. The financial ratios included in the model were The log of the total capital/total assets, log of total loans/total capital, the log of sales of Treasury bills and purchases of securities/total assets, net recoveries of loans/total loans, the log of the loans/total operations expenses loss reserves, the log of the total cost of a loan/net income plus reserves for loan losses, the log of the commercial and industrial/total loans, real estate mortgage/total loans, loans interests/net loans, and total operations/total assets, net income/total assets, net income/total capital, net income/total operating income, total loans/total deposits, total loans/total assets, log of cash and securities/Total assets, log of domestic securities/total assets, and the log of purchases of Treasury bills and sales of securities/total assets. The results indicated that the overall accuracy of the Cox model was similar to the model using the discriminant analysis.

All approach includes discriminant analysis, regression analysis, logit analysis or probit analysis are usually requires that data follow certain assumptions, like data normally distributed to generate robust results (Beaver, 1966; Altman, 1968; Beaver, 1968; Deakin, 1972; Ohlson, 1980; Zmijewski, 1983; Platt \& Platt, 1990; Theodossiou, 1991). Although financial data and ratios rarely have a normal distribution to be useful to make the models less sensitive to non-normal distributions.

In this research, we try to use neural network technique to avoid the assumption of the previous techniques, but we have a great problem with this technique due to the nature of financial distress. Financial distress is a complicated phenomenon needs many financial ratios to diagnose it, so with a large number of ratios the accuracy of the neural model deteriorated, as the dispersion of the data become bigger, so as a solution we built scenarios to predict financial distress. With multi-scenario modeling, the model can easily applied in different countries and different periods, as it has many scenarios can detect the financial distress phenomenon.

\section{Description of Data and Sample}

To predict financial distress, we use a sample of 37 companies listed on "EGX 100 index", the total observation is 259,82 observation omitted as some data are missing, so 177 observation will be analyzed. The sample period is eight years from 2001 to 2008 to isolate the effects of global financial Depression in 2008, and the effect of economic instability, which coincided with the Egyptian revolution in 2011 tell now. 
Table 1. Model variables

\begin{tabular}{lcl}
\hline Ratio & symbol & Prior researchers \\
\hline Net profit / total assets & Y1 & Beaver, Deakin, Ohlson, Zavgren, Zmijewski, Casy, Lane, Theodossiou \\
Net profit / equity & Y2 & Blum, Mensah \\
Net profit / sales & Y3 & Mensah \\
Operational profit / sales & Y4 & Mensah \\
Operational profit / total assets & Y5 & Mensah, Lane \\
Current assets / current liabilities & Y6 & Beaver, Deakin, Zmijewski, Casy, Mensah, Sharma \\
Net fixed assets / total assets & Y7 & Platt \\
Inventory / current assets & Y8 & \\
Cash / current liabilities & Y9 & Deakin, Mansah, Norton \\
(current assets - inventory)/current liabilities & Y10 & Deakin, Zavgren, Theodossiou, Edmister \\
Cash / total assets & Y11 & Deakin, Zavgren, Norton, Casy \\
Current assets / total assets & Y12 & Deakin, Norton, Casy \\
Inventory / total assets & Y13 & Desheng \\
(current assets - inventory) / total assets & Y14 & Deakin, Norton \\
Total liabilities / total assets & Y15 & Mensah, Theodossiou, Platt \\
Current liabilities / total assets & Y16 & Mensah \\
Long term liabilities / total assets & Y17 & Beaver, Deakin \\
Operational profit / interest & Y18 & Rushink \\
Equity / net fixed assets & Y19 & Norton \\
Equity / total liabilities & Y20 & Norton \\
Sales / inventory & Y21 & Norton, Sharma, Mensah, Zavgren \\
Cash / sales & Y22 & Deakin, Platt, Laitinen \\
\hline
\end{tabular}

\section{Methodology}

To build a predictive model we must first identify the distressed and non-distressed firms, then next analyze the firms with financial ratios, in order to use this ratios to build scenarios for predicting financial distress so the research divided into three main categories first identify the distress, second build scenarios and third predict using neural network

\subsection{Identify the Distress}

To identify the distressed and non-distressed firms, we use altman Z-score estimated for non-manufacturers and emerging markets, Z-score model function is

$$
Z=6.56 \times 1+3.26 \times 2+6.72 \times 3+1.05 \times 4
$$

Where

$\mathrm{X} 1=$ Working capital / total assets

$\mathrm{X} 2$ = Retained earnings / total assets

$\mathrm{X} 3=$ EBIT $/$ total assets

$\mathrm{X} 4$ = Equity / total liabilities

The firm will be distressed if the score is between 1.1 and 2.6, and if the score is equal or more than 2.6 it will be a non-distressed firms. To distinguish between distressed and non-distressed firms for the neural network, we will use a dummy variable, the distressed firma will take value 1 and non-distressed firms will take value 0 .

\subsection{Build Scenarios}

In order to build the scenarios we use 22 financial ratio from the literature of finance as shown in table 1. In each year of the sample period, we will compute the ratios " $\mathrm{y} 1, \mathrm{y} 2 \mathrm{y} 3, \mathrm{y} 4 \ldots \mathrm{y} 22$ " to build the model. Factor analysis will Use the previous y ratios to build the scenarios, which will mainly reduce the data dimensions and enhance the accuracy of the neural network, will use the weight of every ratio in each factor to determine the meaning of each factor as a probable scenario for distress.

\subsection{Predict Using Neural Network}

Neural network will deal with the factors generated from the factor analysis, which will be the probable scenarios for distress, and then we will examined all this scenarios in the neural network to determine its 
explanatory power. The type of the neural network that will be used is multilayer perceptron network, it will be trained by $72 \%$ of the total observations, and then network will be tasted with $19 \%$ of the total observation and tested the final model with $9 \%$ of total observations. The network will be trained using two functions:

First function of processing layers is Hyperbolic tangent.

$$
\gamma(c)=\tanh (c)=(e c-e-c) /(e c+e-c)
$$

It takes real-valued arguments and transforms them to the range $(-1,1)$, which suits the value of the factors, this is the activation function for all units in the hidden layers.

the second function of output layer (softmax function) is

e: natural logarithm

$$
\frac{e^{x}}{\sum_{i} e^{x_{i}}}
$$

$\mathrm{x}$ : input from the hidden layers

i: number of layer

The value of this function is the zero or one matches with the dummy variable of distress.

\section{Results}

\subsection{Factor Analysis}

factor analysis generates six factors, each factor is a scenario for financial distress, With revising the weight of each ratio in the factor in table 2, we can determining the mean of each scenario

\subsubsection{First Scenario}

The company will be distressed if there is a decreasing in liquidity, decreasing in generating cash from sales with increasing in financial leverage

\subsubsection{Second Scenario}

The company will be distressed if there is an increasing in debt and liabilities with decreasing in liquidity and equity, with decreasing in operational leverage.

\subsubsection{Third Scenario}

The company will be distressed if there is a decreasing in liquidity and profitability appears in both return on asset and equity.

\subsubsection{Fourth Scenario}

The company will be distressed if there is an increasing in inventory with decreasing in sales.

\subsubsection{Fifth Scenario}

The company will be distressed if there is overinvestment in assets with financing from debt and long term loans.

\subsubsection{Sixth Scenario}

The company will be distressed if there is a decreasing in operational leverage, sales and profitability.

Table 2. Rotated component factor matrixa

\begin{tabular}{lllllll}
\hline & \multicolumn{1}{l}{ Component } & & & & \\
\cline { 2 - 6 } & $\mathrm{f} 1$ & $\mathrm{f} 2$ & $\mathrm{f} 3$ & $\mathrm{f} 4$ & $\mathrm{f5}$ & $\mathrm{f6}$ \\
\hline Y10 & .883 & & & & \\
Y6 & .858 & & & & \\
Y9 & .839 & & & & \\
Y20 & .832 & & & & \\
Y11 & .641 & & & & \\
Y16 & & .889 & & & & \\
Y14 & .360 & .887 & & & & \\
Y12 & & .876 & & & & \\
Y15 & & .669 & & & & \\
Y19 & & .543 & & & & \\
\hline
\end{tabular}




\begin{tabular}{lllll}
\hline Y4 & .508 & .404 & & .465 \\
Y1 & & .894 & & \\
Y2 & & .887 & & \\
Y5 & & .886 & & \\
Y8 & & & .901 & \\
Y13 & .401 & .831 & & \\
Y21 & & $-.492-$ & .396 & \\
Y17 & & & .916 & \\
Y7 & & & .697 & .863 \\
Y3 & & & & .806 \\
Y22 & & & & \\
\hline
\end{tabular}

\subsection{Neural Network}

After training the neural network, the network appears as the shown in Figure 1. We can see that the neural network have 12 processing layer with 2 output layers for the distress dummy variable.

Table 3 shows the accuracy of the final network is $100 \%$ in distinguish between distressed and non-distressed companies.

Table 4 shows the importance of each scenario in predicting financial distress, first scenario is the most important with $100 \%$, then second scenario with importance of $75.9 \%$, third scenario with importance of $75.9 \%$, fourth scenario with importance of $64.3 \%$, fifth scenario with importance of $36.5 \%$, sixth scenario with importance of $47.4 \%$ for distress in Egypt. This meant that the first scenario is the most important and probable scenario for distress in the Egyptian stock market, which can refer to bad management for short term assets.

Table 3. Results of neural network

\begin{tabular}{lcccc}
\hline Sample & Observed & \multicolumn{3}{c}{ Predicted } \\
\cline { 3 - 5 } & & 0 & 1 & Percent Correct \\
\hline \multirow{3}{*}{ Training } & 0 & 64 & 0 & $100.0 \%$ \\
& 1 & 0 & 64 & $100.0 \%$ \\
\multirow{3}{*}{ Testing } & Overall Percent & $50.0 \%$ & $50.0 \%$ & $100.0 \%$ \\
& 0 & 15 & 1 & $93.8 \%$ \\
\multirow{4}{*}{ Holdout } & 1 & 0 & 17 & $100.0 \%$ \\
& Overall Percent & $45.5 \%$ & $54.5 \%$ & $97.0 \%$ \\
& 0 & 10 & 0 & $100.0 \%$ \\
& 1 & 0 & 6 & $100.0 \%$ \\
& Overall Percent & $62.5 \%$ & $37.5 \%$ & $100.0 \%$ \\
\hline
\end{tabular}




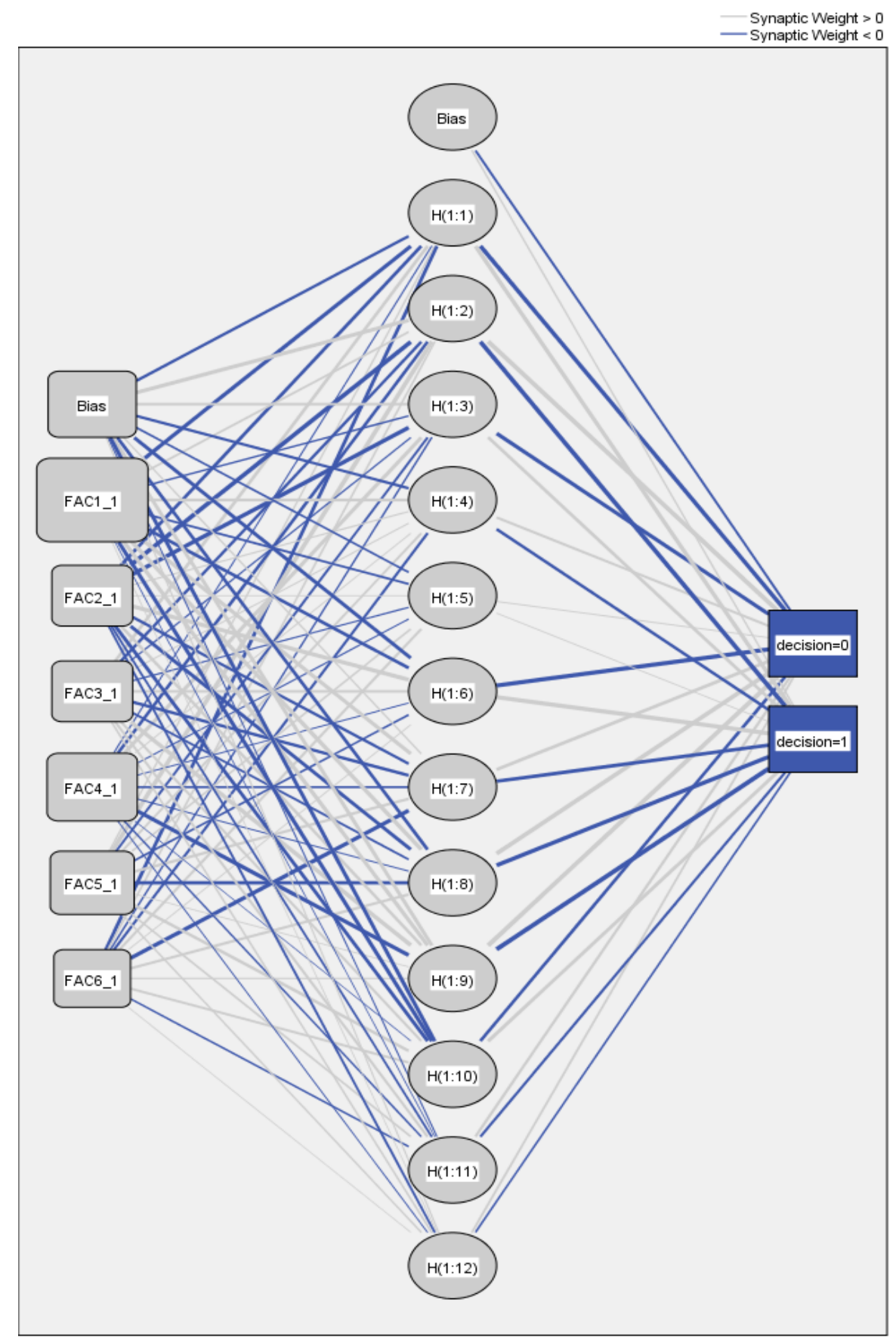

Hidden layer activation function: Hyperbolic tangent Output layer activation function: Softmax

Figure 1. Multilayer perceptron neural network

Table 4. Importance of factors (scenarios)

\begin{tabular}{lll}
\hline & Importance & Normalized Importance \\
\hline Factor 1 & .253 & $100.0 \%$ \\
Factor 2 & .192 & $75.9 \%$ \\
Factor 3 & .181 & $71.5 \%$ \\
Factor 4 & .163 & $64.3 \%$ \\
Factor 5 & .092 & $36.5 \%$ \\
factor 6 & .120 & $47.4 \%$ \\
\hline
\end{tabular}




\section{Conclusion}

The study tries to determine the best scenario to predict financial distress using neural network model. The results show evidence that the best scenario for predicting distress in Egypt is that the company will be distressed if there is a decreasing in liquidity, decreasing in generating cash from sales with increasing in financial leverage. The most important issue is that we can now use this model in different countries as it is a multi-scenario model, each country will have its own scenario, which will be one of the above scenarios. Researchers can use it and determine the most common scenario in his country, as these scenarios will determine the causes of distress, and help in avoiding the bad effects of distress.

\section{References}

Altman, E. I. (1968). Financial Ratios, Discriminant Analysis and the Prediction of Corporate Bankruptcy. The Journal of Finance, 23(4), 589-609. http://dx.doi.org/10.2307/2978933

Altman, E. I., Haldeman, R. G., \& Narayanan, P. (1977). ZETATM analysis A new model to identify bankruptcy risk of corporations. Journal of Banking \& Finance, 1(1), 29-54. http://dx.doi.org/10.1016/0378-4266(77)90017-6

Altman, E., \& Hotchkiss, E. (2006). Corporate financial distress and bankruptcy predict and avoid bankruptcy, analyze and invest in distressed debt (3rd ed.). Hoboken, N.J.: Wiley.

Beaver, W. H. (1966). Financial Ratios As Predictors of Failure. Journal of Accounting Research, 4, 71-111. http://dx.doi.org/10.2307/2490171

Blum, M. (1974). Failing Company Discriminant Analysis. Journal of Accounting Research, 12(1), 1-25. http://dx.doi.org/10.2307/2490525

Casy, C., \& Bartcazk, N. (1984). Cash flow it's not the bottom Line. Harvard Business Review, 84, 61-66.

Deakin, E. B. (1972). A Discriminant Analysis of Predictors of Business Failure. Journal of Accounting Research, 10(1), 167-179. http://dx.doi.org/10.2307/2490225

Edmister, R. (1972). An Empirical Test of Financial Ratio Analysis for Small Business Failure Prediction. The Journal of Financial and Quantitative Analysis, 7(2), 1477-1493. http://dx.doi.org/10.2307/2329929

Izan, H. (1984). Corporate distress in Australia. Journal of Banking \& Finance, 8(2), 303-320. http://dx.doi.org/10.1016/0378-4266(84)90010-4

Johnsen, T., \& Melicher, R. (1994). Predicting corporate bankruptcy and financial distress: Information value added by multinomial logit models. Journal of Economics and Business, 46(4), 269-286. http://dx.doi.org/10.1016/0148-6195(94)90038-8

Laitinen, E. (1993). Financial predictors for different phases of the failure process. OMEGA, 21(2), 215-228. http://dx.doi.org/10.1016/0305-0483(93)90054-o

Lane, W., Looney, S., \& Wansley, J. (1986). An application of the cox proportional hazards model to bank failure. Journal of Banking \& Finance, 10(4), 511-531. http://dx.doi.org/10.1016/s0378-4266(86)80003-6

Mensah, Y. (1983). The Differential Bankruptcy prediction Ability of specific price level adjustment some empirical evidence. The Accounting Review, 58(2), 228-246.

Mensah, Y. (1984). An Examination of the Stationarity of Multivariate Bankruptcy Prediction Models: A Methodological Study. Journal of Accounting Research, 22(1), 380-395. http://dx.doi.org/10.2307/2490719

Norton, C., \& Smith, R. (1979). A Comparison of General Price Level and Historical Cost Financial Statement in the prediction of Bankruptcy. The Accounting Review, 54(1), 72-87.

Ohlson, J. (1980). Financial Ratios and the Probabilistic Prediction of Bankruptcy. Journal of Accounting Research, 18(1), 109-131. http://dx.doi.org/10.2307/2490395

Platt, H., \& Platt, M. (1990). Development Of A Class Of Stable Predictive Variables: The Case Of Bankruptcy Prediction. Journal of Business Finance \& Accounting, 17(1), 31-51. http://dx.doi.org/10.1111/j.1468-5957.1990.tb00548.x

Platt, H., Platt, M., \& Pedersen, J. (1994). Bankruptcy Discrimination With Real Variables. Journal of Business Finance \& Accounting, 21(4), 491-510. http://dx.doi.org/10.1111/j.1468-5957.1994.tb00332.x

Rushinek, A., \& Rushinek, S. (1987). Using financial ratios to predict insolvency. Journal of Business Research, 93-100. http://dx.doi.org/10.1016/0148-2963(87)90021-x 
Sharma, S., \& Mahajan, V. (1980). Early Warning Indicators of Business Failure. Journal of Marketing, 44(4), 80-89. http://dx.doi.org/10.2307/1251234

Theodossiou, P. (1991). Alternative Models For Assessing The Financial Condition Of Business In Greece. Journal of Business Finance \& Accounting, $18(5), \quad$ 697-720. http://dx.doi.org/10.1111/j.1468-5957.1991.tb00233.x

Wilson, R., \& Sharda, R. (1994). Bankruptcy prediction using neural networks. Decision Support Systems, 11(5), 545-557. http://dx.doi.org/10.1016/0167-9236(94)90024-8

Wu, D., Liang, L., \& Yang, Z. (2008). Analyzing the financial distress of Chinese public companies using probabilistic neural networks and multivariate discriminate analysis. Socio-Economic Planning Sciences, 42(3), 206-220. http://dx.doi.org/10.1016/j.seps.2006.11.002

Zavgren, C., \& Zavgren, C. (1983). The Prediction of Corporate Failure: the State of the Art. Journal of Accounting Literature, 10, 78-87.

Zmijewski, M. (1984). Methodological Issues Related to the Estimation of Financial Distress Prediction Models. Journal of Accounting Research, 22, 59-82. http://dx.doi.org/10.2307/2490859

\section{Copyrights}

Copyright for this article is retained by the author(s), with first publication rights granted to the journal.

This is an open-access article distributed under the terms and conditions of the Creative Commons Attribution license (http://creativecommons.org/licenses/by/4.0/). 